\title{
Richness and distribution of aquatic macrophytes in Brazilian semi-arid aquatic ecosystems
}

\author{
Riqueza e distribuição de macrófitas aquáticas em ecossistemas aquáticos do semi-árido brasileiro
}

Gustavo Gonzaga Henry-Silva, Rodrigo Sávio Teixeira de Moura and Luciana Lúcia de Oliveira Dantas

Laboratório de Limnologia e Qualidade de Água do Semi-Árido - LIMNOAQUA, Departamento de Ciências Animais, Universidade Federal Rural do Semi-Árido - UFERSA, CEP 59625-900, Mossoró, RN, Brazil

e-mail: gustavo@ufersa.edu.br, rosatemo@bol.com.br, lucianaoli_dantas@yahoo.com.br

\begin{abstract}
Aim: The aim of this study was to evaluate the richness and distribution of the aquatic macrophytes in the basin of the Apodi/Mossoró River, in the semi-arid region (caatinga) of Rio Grande do Norte, Brazil; Methods: A survey of the floristic composition of the aquatic macrophytes was made at 20 sampling stations in the basin at four seasons (August/2007, November/2007, February/2008, May/2008). Specimens of each species were collected and deposited in the Dárdano de Andrade Lima Herbarium of the Universidade Federal Rural do Semi-Árido; Results: We found 40 species of aquatic macrophytes, in 33 genera and 22 families. The families with the most species were Poaceae and Cyperaceae, and the most species-rich genera were Cyperus and Eleocharis. The most common plant form was amphibian (42.5\%), followed by emergent $(27.5 \%)$, free-floating (12.5\%), rooted-submersed (10.0\%), and floating-leaved (7.5\%). The lowest richness was observed at the estuarine region (3 species), and the highest richness in the upper basin (17 species). The rooted-submersed Hydrothrix gardneri Hooker $\mathrm{f}$. and Ceratophyllum demersum L. were observed in great abundance and frequency in the Santa Cruz Reservoir of Apodi, especially in areas close to cage farms of Nile tilapia (Oreochromis niloticus) (Linnaeus, 1758). The most common free-floating species were Eichhornia crassipes (Mart.) Solms., Pistia stratiotes L., and Salvinia auriculata Aubl., predominantly in stretches that run through urban centers; Conclusion: The species richness of aquatic macrophytes in aquatic environments of the caatinga is similar to that observed in other basins of Brazil. Because of the many dams and reservoirs in the semi-arid Northeast, inventory and monitoring of aquatic macrophytes have become essential, especially in basins that will receive water from the diversion of the São Francisco River.
\end{abstract}

Keywords: aquatic plants, floristic inventory, basin, water diversion, caatinga.

Resumo: Objetivo: Nós objetivamos avaliar a riqueza e a distribuição das macrófitas aquáticas nos ambientes aquáticos da bacia hidrográfica do Rio Apodi/Mossoró, no semi-árido do Rio Grande do Norte; Métodos: A investigação da composição florística das macrófitas aquáticas presentes em 20 estaçôes de amostragem da bacia hidrográfica, em quatro épocas do ano (Agosto/2007, Novembro/2007, Fevereiro/2008, Maio/2008). As espécies foram coletadas e depositadas no herbário Dárdano de Andrade Lima da Universidade Federal Rural do Semi-Árido; Resultados: Foram identificadas 40 espécies de macrófitas aquáticas distribuídas em 33 gêneros e 22 famílias. As famílias com o maior número de espécies foram Poaceae e Cyperaceae e os gêneros mais representativos foram Cyperus e Eleocharis. A forma biológica mais freqüente foi a anfíbia (42,5\%), seguida pelas emergentes $(27,5 \%)$; folhas flutuantes $(12,5 \%)$; submersas enraizadas $(10,0 \%)$ e com folhas flutuantes $(7,5 \%)$. A menor riqueza foi observada na região estuarina (três espécies), e a maior riqueza na parte alta da bacia hidrográfica (dezessete espécies). As submersas enraizadas Hydrothrix gardneri Hooker f. e Ceratophyllum demersum L. foram observadas em grande abundância e frequência no reservatório de Santa Cruz do Apodi, especialmente em áreas próximas as atividades de criação em tanques rede de tilápia do Nilo (Oreochromis niloticus) (Linnaeus, 1758). As flutuantes livres de maior ocorrência foram Eichhornia crassipes (Mart.) Solms., Pistia stratiotes L., e Salvinia auriculata Aubl., ocorrendo predominantemente em trechos que atravessam centros urbanos; Conclusóes: Nós concluímos que a riqueza de espécies de macrófitas aquáticas em ambientes aquáticos associados ao bioma caatinga é semelhante à riqueza observada em outras bacias hidrográficas do Brasil. Devido a grande quantidade de açudes e reservatórios existentes no semi-árido nordestino, o levantamento e o monitoramento das macrófitas aquáticas tornam-se essenciais, especialmente em bacias hidrográficas que receberão água da transposição do rio São Francisco.

Palavras-chave: plantas aquáticas, levantamento florístico, bacia hidrográfica, transposição de água, caatinga. 


\section{Introduction}

The principal characteristics of the Brazilian semi-arid region are the low rainfall, generally concentrated in certain periods of the year; and the narrow temperature range (Maltchik and Florín, 2002). Studies on aquatic ecosystems of the Brazilian semi-arid region have evidenced the high biodiversity of these environments, including aquatic macrophytes, and have demonstrated that patterns of diversity are related to the hydrological extremes of flood and drought (Medeiros and Maltchik, 1999; Silva-Filho and Maltchik, 2000; Medeiros and Maltchik, 2001; Pedro et al., 2006).

Aquatic macrophytes play an important role in the structure and function of the aquatic environment (Engelhardt and Ritchie, 2001; Chambers et al., 2008; Makkay et al., 2008). Many studies have demonstrated the influence of these plants on the communities of benthic macro-invertebrates (Van den Berg et al., 1997; Takeda et al., 2003), fishes (Agostinho et al., 2003; Pelicice et al., 2005; Sánchez-Botero et al., 2008), periphyton (Pompêo and Moschini-Carlos, 2003), and zooplankton (Lansac-Toha et al., 2003). Floristic inventories have provided essential information for the conservation of biodiversity (Camargo et al., 2003; França et al., 2003; Matias et al., 2003; Paz and Bove, 2007; Rocha et al., 2007; Mora-Olivo and Villaseñor, 2007; Martins et al., 2008; Pivari et al., 2008a).

In recent years, studies of aquatic macrophyte communities have intensified, not only because of the ecological importance of these plants, but also because of the possibility of using them as biological indicators, as well as the proliferation of some species in basins impacted by organic pollution, reservoir construction, and water diversion (Pieterse and Murphy, 1990; Mackay et al., 2003; Thomaz et al., 2003; Camargo et al., 2003; Martins et al., 2008). The two largest drainage basins of the State of Rio Grande do Norte (Piranhas/Açu and Apodi/ Mossoró) will receive water from the São Francisco River through the Eixo Norte (North Axis) waterway (ANA, 2007). These basin-integration projects may lead to physical and chemical changes of the water, and will also mix the aquatic biological communities through the introduction of species from one basin to another.

Considering that floristic inventories are important to provide useful information for actions to preserve biodiversity and in the management of weeds, and that studies on aquatic macrophytes in the semi-arid region of Rio Grande do Norte are few, the present work aimed to evaluate the richness and distribution of the aquatic macrophytes in the basin of the Apodi/Mossoró River, in order to compare and understand possible changes in the assemblages of aquatic macrophytes after artificial diversion of the Sao Francisco River.

\section{Material and Methods}

\subsection{Study area}

The basin of the Apodi/Mossoró River is located in the Northeast Middle-Eastern river basin of the State of Rio Grande do Norte ( $6^{\circ} 22^{\prime} 08^{\prime \prime}$; $4^{\circ} 57^{\prime} 15^{\prime \prime} \mathrm{S}$ and $\left.38^{\circ} 27^{\prime} 22^{\prime \prime} ; 37^{\circ} 8^{\prime} 11^{\prime \prime} \mathrm{W}\right)$. The aquatic ecosystems of this region lie in the semi-arid Caatinga, and the rivers are intermittent except in their lower, tidal reaches, and in stretches where reservoirs have been constructed. In most of the basin, the annual mean rainfall is about $700 \mathrm{~mm}$ (SEMARH, 2009). The basin covers an area of $14,276 \mathrm{~km}^{2}$, and is the largest drainage basin in the state of Rio Grande do Norte, comprising $26.8 \%$ of its area. The basin contains 618 recorded reservoirs (27.4\% of the total in the state), all of which may be susceptible to colonization by exotic species. The headwaters of the Apodi/Mossoró River are in the mountains near the city of Luís Gomes in western Rio Grande do Norte, at $831 \mathrm{~m}$ altitude. The basin is $210 \mathrm{~km}$ long, and its largest reservoir, Santa Cruz, has an area of $2,187.5 \mathrm{~km}^{2}$ and a maximum water storage capacity of $600,000,000 \mathrm{~m}^{3}$. Only downstream from the Santa Cruz Reservoir is the Apodi/Mossoró River entirely perennial (SEMARH, 2009).

\subsection{Sampling}

In order to evaluate the richness and distribution of the aquatic macrophytes, samples of plant material were obtained at three-month intervals (August/2007, November/2007, February/2008, May/2008) at 20 sampling stations in the Apodi/ Mossoró River basin (Figure 1). In the sampling stations, we made random walks up to $2 \mathrm{~m}$ from the shoreline, during 30 minutes; at some stations we used a boat. The specimens collected were photographed and placed in exsiccatae for subsequent cataloging in the Dárdano de Andrade Lima Herbarium of the Universidade Federal Rural do Semi-Árido. Species were identified through morphological comparison and consultation of specialized literature (Hoehne, 1979; Joly, 1987; Cook, 1990; Velásquez, 1994; Irgang and Gastal, 1996; Lorenzi, 2000; Pott, VJ. and Pott, A., 2000) 

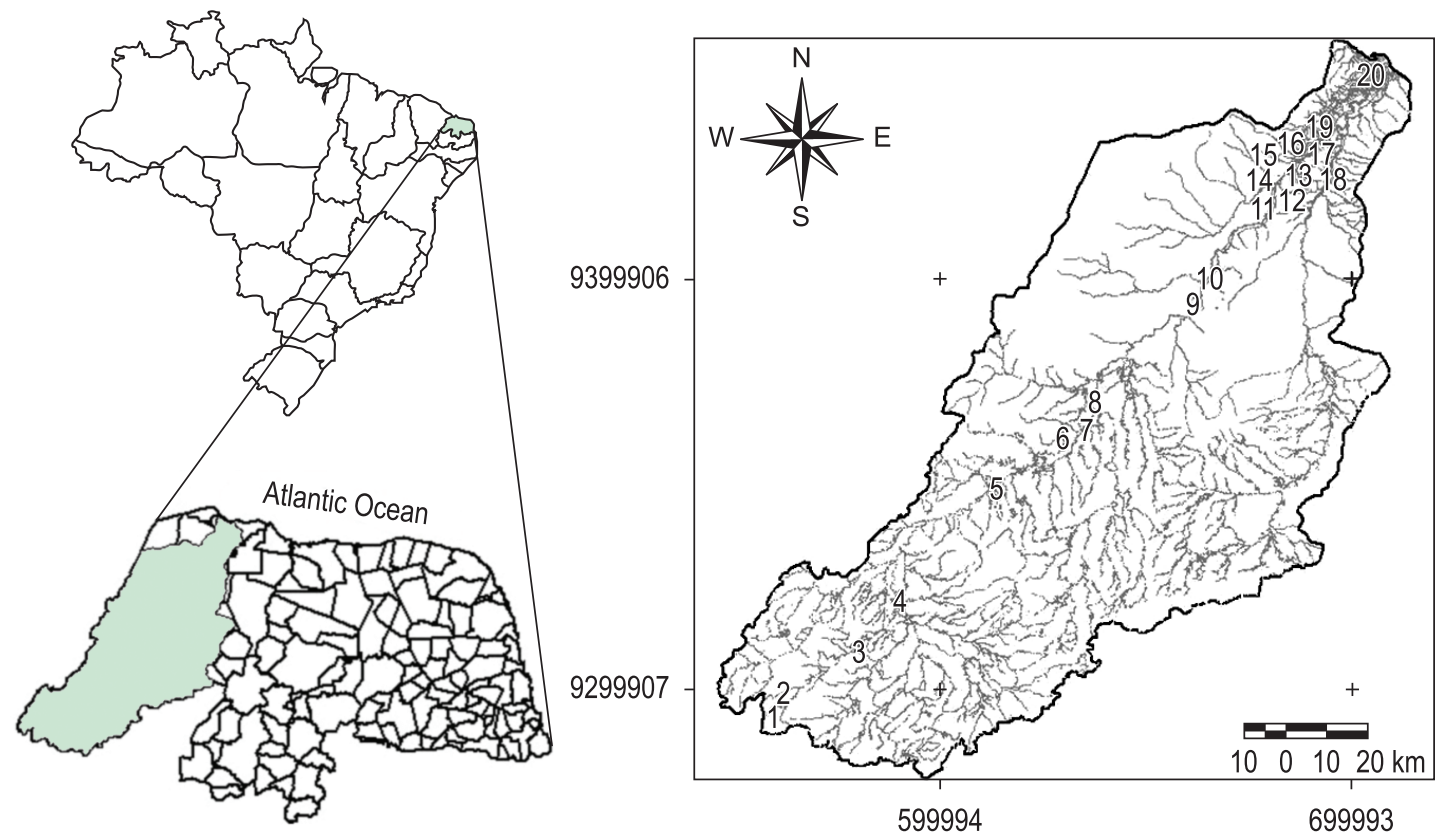

Figure 1. Location and hydrography of the Apodi/Mossoró river basin, RN, Northeast Brazil, with the 20 sampling station. Geographical coordinates: Station 1: $06^{\circ} 22^{\prime} 10^{\prime \prime} \mathrm{S}$ and $038^{\circ} 27^{\prime} 39^{\prime \prime} \mathrm{W}$; Station 2: $06^{\circ} 22^{\prime} 08^{\prime \prime} \mathrm{S}$ and $038^{\circ} 27^{\prime} 27^{\prime \prime}$ W; Station 3: $06^{\circ} 14^{\prime} 05^{\prime \prime}$ S and 038 14' 54" W; Station 4: $06^{\circ} 08^{\prime} 05^{\prime \prime}$ S and $038^{\circ} 11^{\prime} 35^{\prime \prime}$ W; Station 5: $06^{\circ} 16^{\prime} 88^{\prime \prime} \mathrm{S}$ and $038^{\circ} 15^{\prime} 70^{\prime \prime} \mathrm{W}$; Station 6: $05^{\circ} 45^{\prime} 68^{\prime \prime} \mathrm{S}$ and $037^{\circ} 48^{\prime} 15^{\prime \prime} \mathrm{W}$; Station 7: $05^{\circ} 45^{\prime} 08^{\prime \prime} \mathrm{S}$ and $037^{\circ} 47^{\prime} 41^{\prime \prime} \mathrm{W}$; Station 8: $05^{\circ} 40^{\prime} 09^{\prime \prime} \mathrm{S}$ and $037^{\circ} 47^{\prime}$ 59” W; Station 9: $05^{\circ} 28^{\prime} 09^{\prime \prime} \mathrm{S}$ and $037^{\circ} 31^{\prime} 29^{\prime \prime} \mathrm{W}$; Station

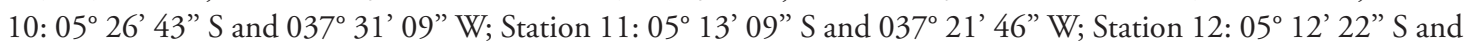

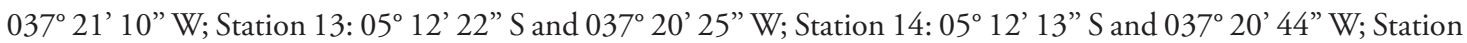

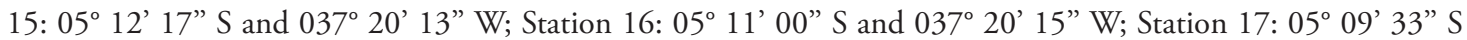

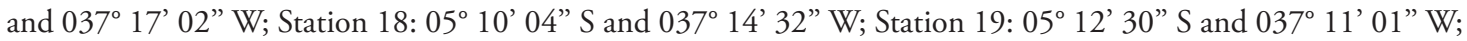
Station 20: $04^{\circ} 57^{\prime} 15^{\prime \prime} \mathrm{S}$ and $037^{\circ} 08^{\prime} 11^{\prime \prime} \mathrm{W}$.

and with experts. The scientific names used here follow the APGII classification system (2003), and the spelling of names was confirmed by the Missouri Botanical Garden (2010).

To categorize the aquatic macrophytes, we used the definitions of Cook (1996) and Irgang and Gastal (1996). The species were classified as amphibian (Am), emergent (Em), free-floating (FF), rooted-submersed (RS), floating-leaved (FL), and free-submersed (FS). The frequency of occurrence was calculated from the occurrence of each species at the sampling stations at the four periods of the year. Taxa were classified as: Constant $=\mathrm{F}>50 \%$, Common $=10 \%<\mathrm{F} \leq 50 \%$, or Rare $=\mathrm{F} \leq 10 \%$ (Lobo and Leighton, 1986).

\section{Results and Discussion}

In the Apodi/Mossoró River basin were identified 40 aquatic macrophyte species, members of 33 genera and 22 families (Table 1 ). The families with the largest numbers of species were Poaceae and Cyperaceae, comprising 30\% of the total (Figure 2). The most species-rich genera were
Cyperus and Eleocharis, with four and three species, respectively (Figure 3). Both families contain many taxa of aquatic macrophytes (França et al., 2003; Matias et al., 2003; Rocha et al., 2007; Pivari et al., 2008b). Some species of these families can colonize a wide variety of aquatic environments and inhabit ecotone areas (Cook, 1996; Leite et al., 2009). Currently, it is estimated that there are about 10,035 species of Poaceae and 5,000 species of Cypereaceae (Goetghebeur, 1998; Govaerts et al., 2007). Pott, VJ. and Pott, A. (2000), in a study of the distribution of aquatic macrophytes of the Pantanal, identified a total of 273 species, 26 Poaceae and 22 Cyperaceae, together comprising $17.6 \%$ of all species found. The importance of these families in aquatic environments is due to their rhizomes, tubers, and stolons, which facilitate vegetative propagation (Pott et al., 1989; Bove et al., 2003; França et al., 2003; Matias et al., 2003).

The most common biological form of macrophyte was the amphibian (42.5\%), with 17 species, followed by the emergent $(27.5 \%)$, free-floating $(12.5 \%)$, rooted-submersed (10.0\%), and floating- 
Table 1. List of occurrences of species in hydrographic basin of the Apodi/Mossoró River, RN, Northeast Brazil. (Biological forms: $\mathrm{Am}=$ Amphibian, $\mathrm{Em}=$ Emergent, $\mathrm{FL}=$ Floating leaved, $\mathrm{FF}=$ Free-floating, $\mathrm{RS}=$ Rooted submersed).

\begin{tabular}{lll}
\hline Family/Specie & Biological form & Sampling stations \\
\hline
\end{tabular}

\section{Acanthaceae}

Ruellia paniculata L.

\section{Aizoaceae}

Sesuvium portulacastrum (L.) L.

\section{Alismataceae}

Echinodorus grandiflorus (Cham. \& Schltdl.) Micheli

\section{Amaranthaceae}

Blutaparon portulacoides (A. St.-Hil.) Mears

Alternanthera philoxeroides (Mart.) Griseb.

\section{Araceae}

Pistia stratiotes L.

Wolffia brasiliensis Wedd.

\section{Asteraceae}

Eclipta alba (L.) Hassk.

\section{Ceratophyllaceae}

Ceratophyllum demersum $\mathrm{L}$.

Ceratophyllum submersum L.

\section{Chenopodiaceae}

Salicornia gaudichaudianaMoq.

\section{Convolvulaceae}

Ipomoea fistulosa Mart. ex. Choisy

\section{Cyperaceae}

Cyperus esculentus L.

Cyperus gardneri Nees

Cyperus ligularis L.

Cyperus surinamensis Rottb.

Eleocharis acutangula (Roxb.) Schult.

Eleocharis geniculata (L.) Roem. \& Schult.

Eleocharis interstincta (Vahl) Roem. \& Schult.

\section{Fabaceae}

Neptunia plena (L.) Benth.

Stylosanthes guianensis (Aubl.) Sw.

\section{Hidrophyllaceae}

Hydrolea spinosa L.

\section{Lemnaceae}

Lemna valdiviana Phil.

\section{Limnocharitaceae}

Limnocharis flava (L.) Buchenau

Hydrocleys parviflora Seub.

\section{Nymphaeaceae}

Nymphaea alba L.

\section{Onagraceae}

Ludwigia helminthorrhiza (Mart.) H. Hara

Ludwigia peploides (Kunth) P.H. Raven

\section{Poaceae}

Cenchrus echinatus L. Chloris barbata Sw.
Am

14,15

Am

$17,18,19,20$

Em

$1,2,3,4$

Am

Em

FF

FF

Am

$\mathrm{RS}$

RS

Am

Am

Em

Em

Em

Em

Am

Am

Am

Am

Am

Em

FF

Em

FL

FL

FL

Em

Am

Am
$10,11,12,13,14,15,16,18,19,20$

$4,5,7,8,9,11,13,15,16,17,18,19$

$7,8,11,12,13,14,15,16,17$

7

$$
3,4,6,11
$$

5,6

5,6

19

$3,4,7,6,7,8,9,10,11,12,14,16,17,18$

$$
\begin{gathered}
2,3,4,6,7,9,10,13,18 \\
1,2,3,8 \\
4,6,10,13
\end{gathered}
$$$$
3
$$

$3,4,7,8,12,18$

$1,4,6,9,10,14,17,18$

3

$7,10,17,18$ 3

$4,12,13,14$

\section{4}

3

3,4

$4,5,6,7,9,15,16$

$8,10,11,12,13,14,15$

3

$6,12,13,14,15,18$ 
Table 1. Continued...

\begin{tabular}{lcc}
\hline \multicolumn{1}{c}{ Family/Specie } & Biological form & Sampling stations \\
\hline Echinochloa polystachya (Kunth.) Hitchc. & Em & $12,13,14$ \\
$\quad \begin{array}{l}\text { Paspalidium paludivagum (Hitchc.\& Chase) Parodi } \\
\text { Paspalum vaginatum Sw. }\end{array}$ & Em & $4,7,10,15,18$ \\
$\begin{array}{l}\text { Pontederiaceae } \\
\quad \text { Heteranthera seubertiana Solms }\end{array}$ & Am & $11,12,13,14,15,16,17,18$ \\
$\quad$ Eichhornia crassipes (Mart.) Solms & Am & $3,4,8,9,10,11$ \\
$\quad$ Hydrothrix gardneri Hook. f. & FF & $4,10,11,12,13,14,15,16$ \\
$\begin{array}{l}\text { Potamogetonaceae } \\
\text { Ruppia maritima L. }\end{array}$ & RS & $6,9,10$ \\
$\begin{array}{l}\text { Rubiaceae } \\
\text { Borreria alata (Aubl.) DC. }\end{array}$ & RS & 20 \\
$\begin{array}{l}\text { Salviniaceae } \\
\text { Salvinia auriculata Aubl. }\end{array}$ & Am & 3 \\
$\begin{array}{l}\text { Scrophulariaceae } \\
\text { Stemodia maritima L. }\end{array}$ & FF & $4,6,7,10,14,15,16$ \\
\end{tabular}

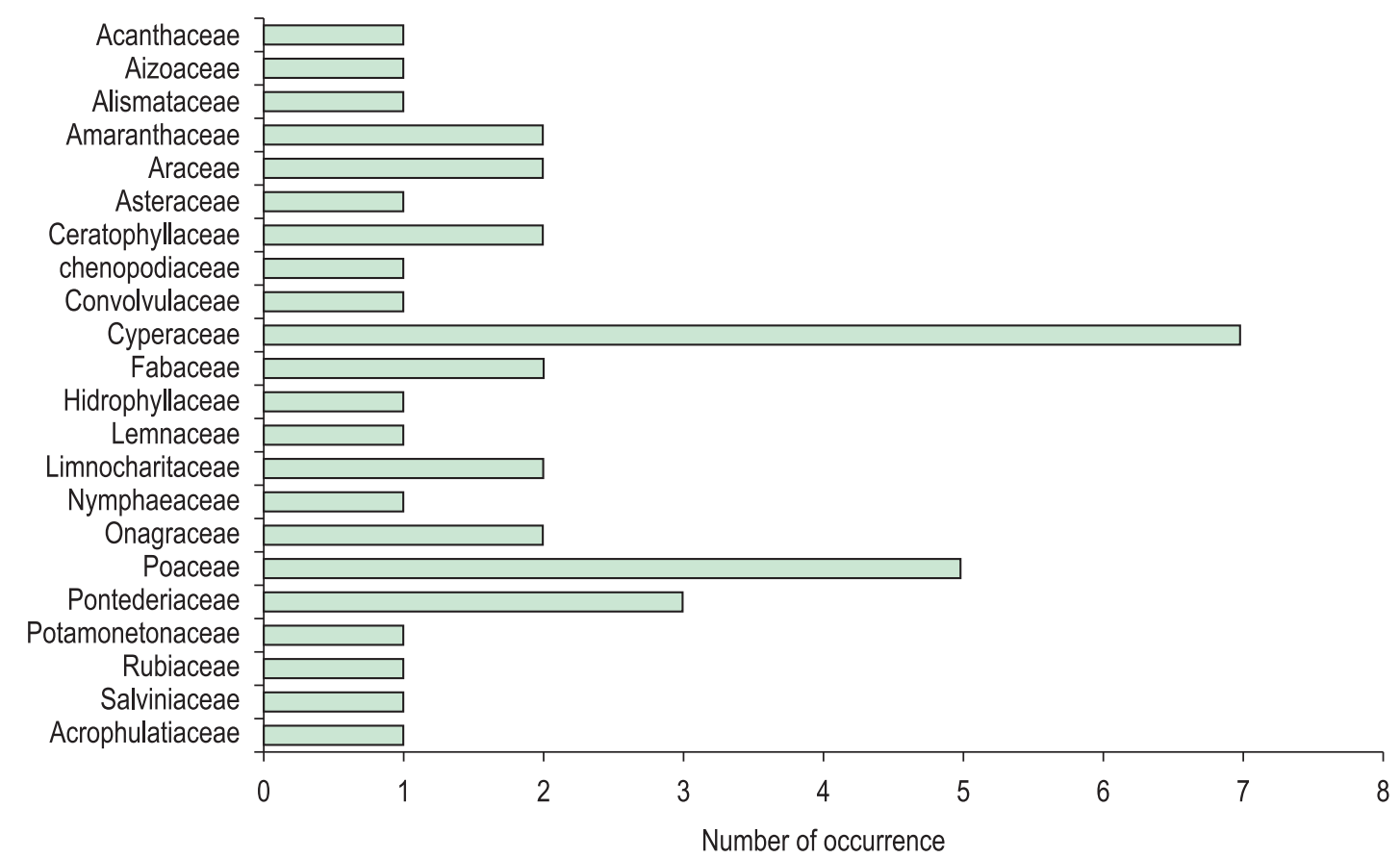

Figure 2. Number of occurrence of species, per family, in 20 sampling stations of the basin of the Apodi/Mossoró River, RN, Northeast Brazil.

leaved (7.5\%) (Figure 4). No free-submersed species were found. The Common species represented $55.0 \%$ of the total of aquatic macrophytes, and the Rare and Constant species represented 37.5\% and $7.5 \%$, respectively. Among the Common species, the amphibian was the most frequent (45.5\%), followed by the emergent $(27,3 \%)$, freefloating $(18,2 \%)$, rooted-submersed (4.5\%), and floating-leaved (4.5\%). Among the Rare species, the amphibian was the most common (40.0\%), followed by the rooted-submersed and emergent (both with 20.0\%), floating-leaved (13.3\%), and free-floating $(6.7 \%)$. Only three biological forms were identified for the Constant species: amphibian (66.7\%), and emergent (33.3\%). (Table 2).

The $47.5 \%$ of the species identified in the Apodi/Mossoró River basin can be considered opportunistic, i.e., they have greater ability to use light, water, nutrients, and carbon dioxide, high seed production, and mechanisms to promote the spread and longevity of seeds, especially through dormancy (Lorenzi, 2000). According to Lorenzi 


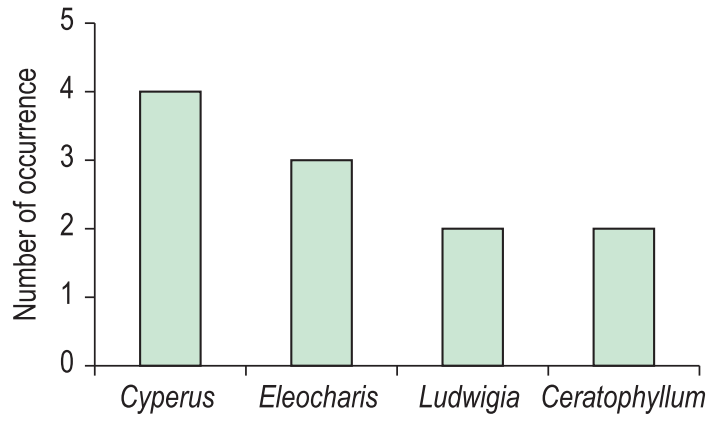

Figure 3. Number of occurrence of species, per principal genera, in 20 sampling stations of the basin of the Apodi/ Mossoró River, RN, Northeast Brazil.

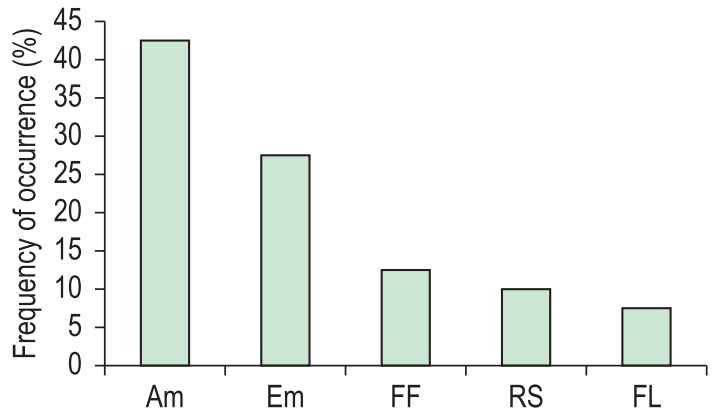

Figure 4. Ranking of biological forms occurrent in the basin of the Apodi/Mossoró River, RN, Northeast Brazil. $\mathrm{Am}=$ Amphibian; Em = Emergent; FF = Free-floating; RS $=$ Rooted-submersed; FL = Floating-leaved.

Table 2. Classification according to frequency of occurrence of aquatic macrophytes from hydrographic basin of the Apodi/Mossoró River, RN, Northeast Brazil.

\begin{tabular}{|c|c|c|}
\hline Species & Occurrence number & Classification \\
\hline Alternanthera philoxeroides (Mart.) Griseb. & 12 & Constant \\
\hline Blutaparon portulacoides (A. St.-Hil.) Mears & 10 & Common \\
\hline Borreria alata (Aubl.) DC. & 1 & Rare \\
\hline Cenchrus echinatus L. & 1 & Rare \\
\hline Ceratophyllum submersum L. & 2 & Rare \\
\hline Ceratophyllum demersum L. & 2 & Rare \\
\hline Chloris barbata Sw. & 6 & Common \\
\hline Cyperus esculentus L. & 9 & Common \\
\hline Cyperus gardneri Nees & 4 & Common \\
\hline Cyperus ligularis L. & 4 & Common \\
\hline Cyperus surinamensis Rottb. & 1 & Rare \\
\hline Echinochloa polystachya (Kunth.) Hitchc. & 3 & Common \\
\hline Echinodorus grandiflorus (Cham. \& Schltdl.) Micheli & 4 & Common \\
\hline Eclipta alba (L.) Hassk. & 4 & Common \\
\hline Eichhornia crassipes (Mart.) Solms & 8 & Common \\
\hline Eleocharis acutangula (Roxb.) Schult. & 6 & Common \\
\hline Eleocharis geniculata (L.) Roem. \& Schult. & 8 & Common \\
\hline Eleocharis interstincta (Vahl) Roem. \& Schult & 1 & Rare \\
\hline Heteranthera seubertiana Solms & 6 & Common \\
\hline Hydrocleys parviflora Seub. & 1 & Rare \\
\hline Hydrolea spinosa L. & 2 & Rare \\
\hline Hydrothrix gardneri Hook. f. & 3 & Common \\
\hline Ipomoea fistulosa Mart. ex. Choisy & 14 & Constant \\
\hline Lemna valdiviana Phil. & 4 & Common \\
\hline Limnocharis flava (L.) Buchenau & 1 & Rare \\
\hline Ludwigia helminthorrhiza (Mart.) H. Hara & 7 & Common \\
\hline Ludwigia peploides (Kunth) P.H. Raven & 7 & Common \\
\hline Neptunia plena (L.) Benth. & 4 & Common \\
\hline Nymphaea alba L. & 2 & Rare \\
\hline Paspalidium paludivagum (Hitchc.\& Chase) Parodi & 5 & Common \\
\hline Paspalum vaginatum Sw. & 8 & Common \\
\hline Pistia stratiotes L. & 9 & Common \\
\hline Ruellia paniculata L. & 2 & Rare \\
\hline Ruppia maritima L. & 1 & Rare \\
\hline Salicornia gaudichaudianaMoq. & 1 & Rare \\
\hline Salvinia auriculata Aubl. & 7 & Common \\
\hline Sesuvium portulacastrum (L.) L. & 4 & Common \\
\hline Stemodia maritima L. & 17 & Constant \\
\hline Stylosanthes guianensis (Aubl.) Sw. & 1 & Rare \\
\hline Wolffia brasiliensis Wedd. & 1 & Rare \\
\hline
\end{tabular}


(2000), the following species can be considered opportunistic: Alternanthera philoxeroides, Cenchrus echinatus, Ceratophyllum demersum, Cyperus esculentus, C. surinamensis, Echinochloa polystachya, Echinodorus grandiflorus, Eclipta alba, Eichhornia crassipes, Eleocharis acutangula, Hydrolea spinosa, Ipomoea fistulosa, Lemna valdiviana, Limnocharis flava, Neptunia plena, Pistia stratiotes, Salvinia auriculata, Stylosanthes guianensis, and Wolffia brasiliensis. Bove et al. (2003), in a study of temporarily flooded environments of the coastal plain of northern Rio de Janeiro, observed that opportunist species represented $23 \%$ of the total taxa, i.e., about half of the proportion found in the present study. This may indicate that the Apodi/ Mossoró River is less preserved, providing favorable conditions for the colonization of potential weed species.

The average richness by sampling station was 9 species, ranging from 3 to 17 species (Figure 5). The stations with the highest richness were 4 and 3 , with 17 and 15 species respectively; amphibians $(41.7 \%)$ and emergents (33.3\%) predominated at both stations. Station 20 presented the lowest species richness (Ruppia maritima, Salicornia gaudiachaudiana, and Sesuvium portulacastrum), probably because it is close to the estuary, where high salinities provide unfavorable habitat for most aquatic macrophytes. Stemodia maritima was the most common species along the river basin, hile the emergent Ludwigia helminthorrhiza and Heteranthera seubertiana occurred in stretches less impacted by domestic-sewage discharge, as well as the submersed genus Ceratophyllum and the species Hydrocleys parviflora. The most common free-floating species were Eichhornia crassipes, Pistia stratiotes, and Salvinia auriculata Aubl, which occurred predominantly in stretches that cross the urban center of the basin.

Most aquatic macrophyte species found in the present survey have wide geographical distributions, and many of them are native to tropical America (Lorenzi, 2000). The rooted submersed Hydrothrix gardneri and Ceratophyllum demersum were observed in great abundance and frequency in the Santa Cruz Reservoir, especially near fish farms where Nile tilapia (Oreochromis niloticus) (Linnaeus, 1758) are raised in cages. The floating-leaved type was less common overall; the species Ludwigia helminthorrhiza, found at eight stations, was most prominent. Nymphaea alba and Hydrocleys parviflora were noted at only one station, just below the Pau dos Ferros Reservoir, in the highest part of the basin.

Compared to other basin-wide inventories of aquatic macrophytes, the present study found species richness similar to that in the Itanhaém River basin (Pereira, 2002) and the Monjolinho River basin (Viana, 2005). However, species richness was relatively low in comparison to other Brazilian wetlands, such as the Banhado do Taim, State of Rio Grande do Sul (Irgang et al., 1984) and the Pantanal (Pott, VJ. and Pott, A., 2000) (Table 3). We found no studies focusing exclusively on hydrophyte communities of the State of Rio Grande do Norte, and in the present study, many temporary

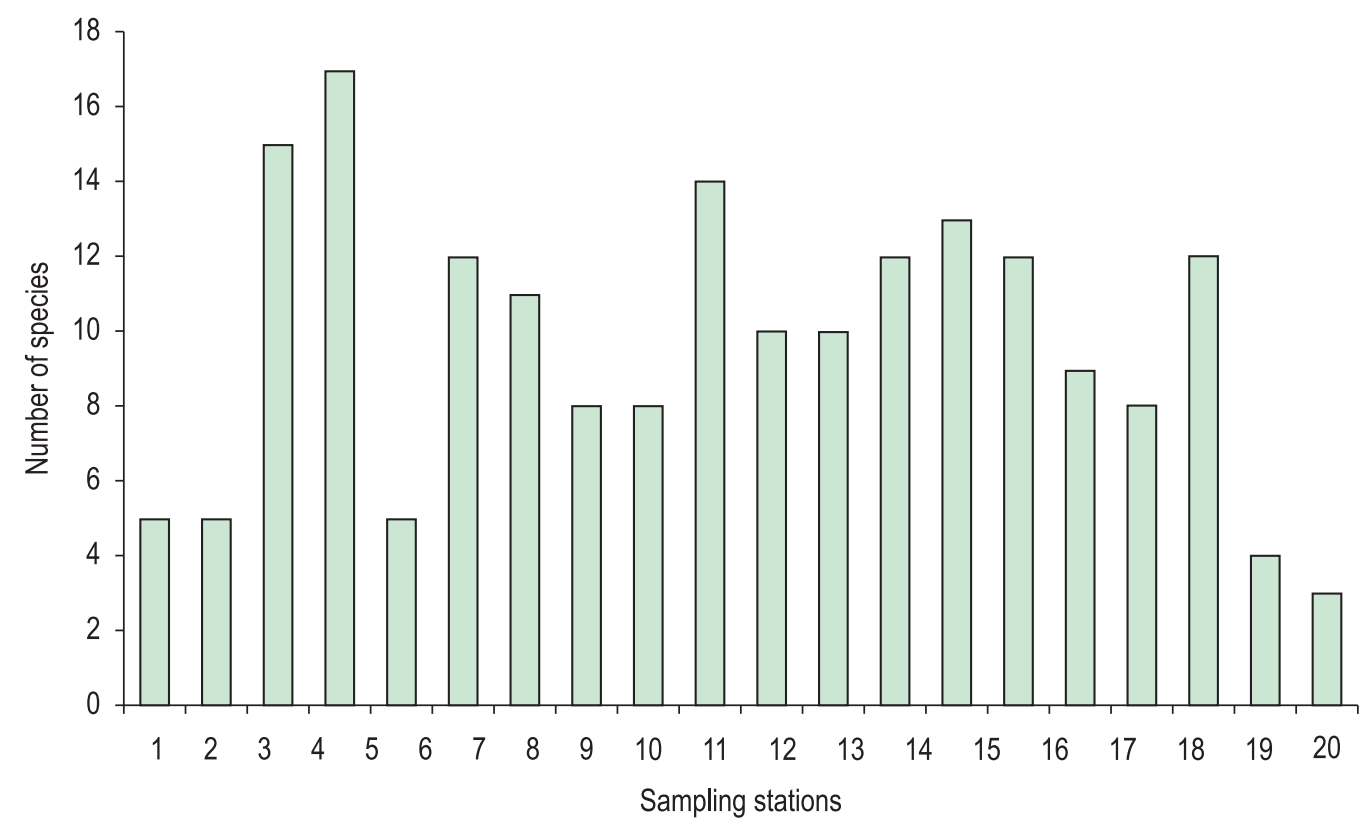

Figure 5. Richness of the species recorded in 20 sampling stations of the basin of the Apodi/Mossoró River, RN, Northeast Brazil. 
Table 3. Comparison of the aquatic macrophytes registered in hydrographic basin of the Apodi/Mossoró River, RN, Northeast Brazil, and in others Brazilian aquatic environmental.

\begin{tabular}{ccccc}
\hline Specie & Genus & Family & Sites & Author \\
\hline 242 & 106 & 54 & Pantanal Mato-grossense - MT & Pott, VJ. and Pott, A. (2000, 2003) \\
189 & 104 & 54 & Pernambuco State & Sobral-Leite et al. (2010) \\
126 & 95 & 53 & Banhado do Taim - RS & Irgang et al. 1984 \\
121 & 92 & 46 & Semi-arid Ponds - et al. (2003) \\
113 & 69 & 40 & Temporary swampy environments - RJ & Bove et al. (2003) \\
89 & 61 & 35 & Pantanal Lakes - MS & Rocha et al. (2007) \\
82 & 62 & 34 & Porto Limão Cárceres Lakes - MT & Silva and Carniello (2007) \\
66 & 48 & 27 & Pantanal Floating Mats - MS & Pivari et al.(2008a) \\
64 & 42 & 26 & Lobo (Broa) Reservoir - SP & Delello (2008) \\
56 & 46 & 35 & Silvana Lake - MG & Pivari et al. (2008b) \\
53 & 25 & 23 & Lakes of the Rio Doce Valley - MG & Tavares (2003) \\
50 & 29 & 18 & Luís Eduardo Magalhães Reservoir - TO & Lolis (2008) \\
45 & 33 & 18 & Jijoca Lake - CE & Matias et al. (2003) \\
42 & 38 & 27 & Carapebus Lake - RJ & Paz and Bove (2007) \\
40 & 33 & 22 & Apodi/Mossoró Hydrographic Basin - RN & Present study \\
39 & 31 & 21 & 18 Reservoirs of the São Paulo State & Martins et al. (2008) \\
35 & 27 & 22 & Itanhaém Hydrographic Basin - SP & Pereira (2002) \\
35 & 28 & 20 & Rosana Reservoir (SP/PR) & Boschilia (2007) \\
31 & 24 & 15 & Monjolinho Hydrographic Basin - SP & Viana (2005) \\
29 & 24 & 19 & Lagoons in Paraná River floodplain - PR/MS & Santos and Thomaz (2007) \\
21 & 33 & 41 & Santana Reservoir - RJ & Pitelli et al..(2008) \\
15 & 13 & 11 & Salto Grande Reservoir - SP & Tavares et al. (2004) \\
\hline
\end{tabular}

environments and reservoirs of the Apodi/Mossoró River basin were not sampled. Thus, the real number of aquatic macrophyte species of this semi-arid basin may be underestimated.

This information indicates that the richness of aquatic macrophytes in the caatinga is similar to that observed in other Brazilian basins. Because of the many dams and reservoirs in the semi-arid Northeast region of Brazil, the inventory and monitoring of aquatic macrophytes supports in evaluating the evolution of these plants, and allows to determine whether some species may become weeds, causing problems for the various uses of these environments. The diversion of water from the São Francisco River to the Apodi/Mossoró River basin may also affect the richness and distribution of the aquatic macrophyte community. Thus, it is essential to monitor the aquatic communities in the lentic and lotic environments of this basin.

\section{Acknowledgements}

We are grateful to professors José Iranildo Miranda de Melo, Regina Célia de Oliveira, and Vali Pott for their help in identifying the aquatic macrophytes species and Anibal de Sousa Mascarenhas Filho and Janet W. Reid of the Biological Consulting and Editing Services -USA by revision manuscript into English. We also thank $\mathrm{CNPq}$ and Petrobras for financial support.

\section{References}

Agência Nacional de Águas. 2007. Boletim de Monitoramento dos Reservatórios do Nordeste do Brasill Agência Nacional de Águas, Superintendência de Usos Múltiplos. Brasília: ANA.

AGOSTINHO, AA., GOMES, LC. and JULIO Jr., HF. 2003. Relaçôes entre macrófitas aquáticas e fauna de peixes. In THOMAZ, S. and BINI, LM. (Eds.). Ecologia e Manejo de Macrófitas Aquáticas. Maringá: Eduem. p. 261-280.

Angiosperm Phylogeny Group - APG. 2003. An update of the Angiosperm Phylogeny Group classification for the orders and families of flowering plants: APG II. Botanical Journal of the Linnean Society, vol. 141, p. 399-436.

BOSCHILIA, SM. 2007. Riqueza, composiçāo e padrōes de co-ocorrência da assembléia de macrófitas aquáticas no reservatório de Rosana (SP/PR). Maringá: Universidade Estadual de Maringá - UEM. [Master thesis].

BOVE, CP., GIL, ASB., MOREIRA, CB. and ANJOS, RFB. 2003. Hidrófitas fanerogâmicas de ecossistemas aquáticos temporários da planície costeira do estado do Rio de Janeiro, Brasil. Acta Botanica Brasilica, vol. 17, no. 1, p. 119-135.

CAMARGO, AFM., PEZZATO, MM. and HENRYSILVA, GG. 2003. Fatores limitantes a produção primária de macrófitas aquáticas. In THOMAZ, SM. and BINI, LM. (Eds.). Ecologia e Manejo de Macrófitas Aquáticas. Maringá: EDUEM, 2003. p. 59-84 
CHAMBERS, PA., LACOUL, P., MURPHY, KJ. and THOMAZ, SM. 2008. Global diversity of aquatic macrophytes in freshwater. Hydrobiologia, vol. 595, no. 1, p. 9-26.

COOK, CDK. 1990. Aquatic Plant Book. The Hague, The Netherlands: SPB Academic Publishing. 228 p.

COOK, CDK. 1996. Water plants of the world. Amsterdan, The Netherlands: SPB Academic Publishing. $557 \mathrm{p}$.

DELELLO, D. 2008. Composição e distribuição (especial e temporal) de macrófitas aquáticas no reservatório do lobo (Broa), Itirapina/Brotas, SP. Escola de Engenharia de São Carlos, São Carlos. [Master thesis].

ENGELHARDT, KAM. and RITCHIE, ME. 2001. Effects of macrophyte species richness on wetland ecosystem functioning and services. Nature, vol. 411, p. 687-689.

FRANÇA, F., MELO, E., GÓES NETO, A., ARAÚJO, D., BEZERRA, MG., RAMOS, HM., CASTRO, I. and GOMES, D. 2003. Flora vascular de açudes de uma região do semi-árido da Bahia, Brasil. Acta Botanica Brasilica, vol. 17, p. 549-559.

GOETGHEBEUR, P. 1998. Cyperaceae. In KUBITZKI, K., HUBER, H., RUDALL, P., STEVENS, P. and STÜTZEL, T. (Eds.). The families and genera of vascular plants. Berlin: Spreng-Verlag. p. 141-190.

GOVAERTS, R., SIMPSON, D., BRUHL, J., EGOROVA, T., GOETGHEBEUR, P. and WILSON, K. 2007. World checklist of Cyperaceae Sedges. Surrey: Kew Gardens. 765 p.

HOEHNE, FC. 1979. Plantas aquáticas. São Paulo: Instituto de Botânica. 168 p.

IRGANG, BE. and GASTAL Jr., CVS. 1996. Macrófitas aquáticas da planicie costeira do RS. Porto Alegre: UFRGS. 290 p.

IRGANG, BE., PEDRALLI, G. and WAECHTER, JL. 1984. Macrófitas aquáticos da estação ecológica do Taim, Rio Grande do Sul, Brasil. Roessleria, vol. 6, no. 1, p. 395-405.

JOLY, AB. 1987. Botânica: introdução à taxonomia vegetal. São Paulo: Nacional. 777 p.

LANSAC-TÔHA, FM., VELHO, LFM. and BONECKER, CC. 2003. Influencia de macrófitas aquáticas sobre a estrutura da comunidade zooplanctônica. In THOMAZ, SM. and BINI, LM. (Eds.). Ecologia e Manejo de Macrófitas Aquáticas. Maringá: Eduem. p. 231-242.

LEITE, KRB., FRANÇA, F. and SCATENA, VL. 2009. Anatomia de espécies anfíbias de Cyperaceae de lagoas do semi-árido, BA, Brasil. Acta Botanica Brasilica, vol. 23, no. 3. p. 786-796.

LOBO, E. and LEIGHTON, G. 1986. Estruturas de las fitocenosis planctonicas de los sistemas de desembocaduras de rio y esteros de la zona central de Chile. Revista de Biologia Marinha, vol. 22, no. 1, p. 143-170.

LOLIS, SF. 2008. Macrófitas aquáticas do reservatório Luís Eduardo Magalhães - Lajeado - Tocantins: biomassa, composição da comunidade e riqueza de espécies. Magingá: Universidade Estadual de Maringá - UEM. [Doctoral thesis].

LORENZI, H. 2000. Plantas daninhas do Brasil: aquáticas, parasitas e tóxicas. Nova Odessa: Instituto Plantarum.

MACKAY, SJ., ARTHINGTON, AH., KENNARD, MJ. and PUSED, BJ. 2003. Spatial variation in the distribution and abundance of submersed macrophytes in an Australian subtropical river. Aquatic Botany, vol. 77, p. 169-186.

MAKKAY, K., PICK, FR. and GILLESPIE, L. 2008. Predicting diversity versus community composition of aquatic plants at the river scale. Aquatic Botany, vol. 88, p. 338-346.

MALTCHIK, L. and FLORIN, M. 2002. Perspectives of hydrological disturbance as the driving force of Brazilian semiarid stream ecosystems. Acta Limnologica Brasiliensia, vol. 14, no. 3, p. 35-41.

MARTINS, D., COSTA, NV., TERRA, MA. and MARCHI, SR. 2008. Caracterização da comunidade de plantas aquáticas de dezoito reservatórios pertencentes a cinco bacias hidrográficas do estado de São Paulo. Planta Daninha, vol. 26, no. 1, p. 17-32.

MATIAS, LQ., AMADO, ER. and NUNES, EP. 2003. Macrófitas aquáticas da lagoa de Jijoca de Jericoacoara, Ceará, Brasil. Acta Botanica Brasilica, vol. 17, no. 4, p. 623-631.

MEDEIROS, ESF. and MALTCHIK, L. 1999. The effects of hydrological disturbance on the intensity of infestation of Lernaea cyprinacea in an stream fish community. Journal Arid of Environments, vol. 43, p. 351-356.

MEDEIROS, ESF. and MALTCHIK, L. 2001. Fish stability and diversity in an intermittent stream from the Brazilian semiarid region. Austral Ecology, vol. 26, p. 156-164.

Missouri Botanical Garden. Tropicos.org. Missouri Botanical Garden. Available from: www.tropicos.org. Access in: 12/01/2010.

MORA-OLIVO, A. and VILLASEÑOR, JL. 2007. Diversidad y distribución de la flora vascular acuática de TAMAULIPAS, México. Journal of the Botanical Research Institute of Texas, vol. 1, no. 1, p. 511-527.

PAZ, J. and BOVE, CP. 2007. Hidrófitas Vasculares da Lagoa de Carapebus, Parque Nacional da Restinga de Jurubatiba, Rio de Janeiro, Brasil. Revista Brasileira de Biociencias, vol. 5, supl. 2, p. 495-497.

PEDRO, F., MALTCHIK, L. and BIANCHINI Jr., I. 2006. Hydrologic cycle and dynamics of aquatic macrophytes in two intermittent Rivers of the semiarid region of Brazil. Brazilian Journal of Biology, vol. 66, no. 2b, p. 575-585.

PELICICE, FM., AGOSTINHO AA. and THOMAZ SM. 2005. Fish assemblages associated with Egeria in a tropical reservoir: Investigating the effects of plant 
biomass and diel period. Acta Oecologica, vol. 27, p. 9-16.

PEREIRA, MCT. 2002. Distribuição e abundância de macrófitas aquáticas em relação às características limnológicas em cinco áreas da bacia do rio Itanhaem, litoral sul do Estado de Sáo Paulo. Rio Claro: Universidade Estadual Paulista "Júlio de Mesquita Filho" - UNESP. 79 p. [Master thesis].

PIETERSE, AH. and MURPHY, JK. 1990. Aquatic weeds. Oxford: Oxford University Press. 593p.

PITELLI, RLCM., TOFFANELI, CM., VIEIRA, EA., PITELLI, RA. and VELINI, ED. 2008. Dinâmica da comunidade de macrófitas aquáticas no reservatório de Santana, RJ. Planta Daninha, vol. 26, no. 3, p. 473-480.

PIVARI, MO., POTT, VJ. and POTT, A. 2008a.) Macrófitas aquáticas de ilhas flutuantes (baceiros) nas sub-regióes do Abobral e Miranda, Pantanal, MS, Brasil. Acta Botanica Brasilica, vol. 22, no. 2, p. 563-571.

PIVARI, MOD., SALIMENA, FRG., POTT, VJ. and POTT, A. 2008b. Macrófitas aquáticas da lagoa de Silvana, vale do rio doce, Minas Gerais, Brasil. Acta BotanicaBrasilica, vol. 22, no. 2, p. 563-571.

POMPÊ, MLM. and MOSCHINI-CARLOS, V. 2003. Macrófitas aquáticas e perifíton. Aspectos ecológicos e metodológicos. Sáo Carlos: Rima. 134 p.

POTT, VJ. and POTT, A. 2000. Plantas aquáticas do Pantanal. Brasília: Embrapa. 404 p.

POTT, VJ. and POTT, A. 2003. Dinâmica da vegetação aquática do Pantanal. In: THOMAZ, SM. and BINI, LM. (Eds.). Ecologia e manejo de macrófitas aquáticas. Maringá: Editora da Universidade Estadual de Maringá. p. 145-162.

POTT, VJ., BUENO, NC., PEREIRA, RAC., SALES, SM. and VIEIRA, NL. 1989. Distribuição de macrófitas aquáticas numa lagoa na fazenda Nhumirim, Nhecolândia, Pantanal, MS. Acta Botanica Brasilica, supl. 3, p. 135-168.

ROCHA, CG., RESENDE, UM. and SOUZA LUGNANI, J. 2007. Diversidade de macrófitas em Ambientes aquáticos do IPPAN na Fazenda Santa Emília, Aquidauana, MS. Revista Brasileira de Biociências, vol. 5, supl. 2, p. 456-458.

SÁNCHEZ-BOTERO, JI., ARAUJO-LIMA, CARM. and GARCEZ, DS. 2008. Efeitos dos tipos de estandes de macrófitas aquáticas e variaçóes do oxigênio dissolvido e da temperatura na distribuição de peixes em lagos da várzea amazônica. Acta Limnológica Brasileira, vol. 20, no. 1, p. 45-54.

SANTOS, AM. and THOMAZ, SM. 2007. Aquatic macrophytes diversity in lagoons of a tropical floodplain: The role of connectivity and water level. Austral Ecology, vol. 32, p. 177-190.

Secretaria de Estado do Meio Ambiente e dos Recursos Hídricos - SEMARH. Bacia do rio Apodi/Mossoró. 2007. Available from: http://www.semarh.rn.gov.br. Access in: 10/2009.
SILVA, RMM. and CARNIELLO, MA. 2007. Ocorrência de macrófitas em lagoas intermitentes e permanentes em Porto Limão Cáceres-MT. Revista Brasileira de Biociências, vol. 5, no. 2, p. 519-521.

SILVA-FILHO, MI. and MALTCHIK, L. 2000. Stability of macroinvertebrates to hydrological disturbance by flood and drought in a Brazilian semiarid river. Verhandlungen Internationale Vereinigung für Theoretische und Angewandte Limnologie, vol. 27, p. 2661-2466.

SOBRAL-LEITE, M., CAMPELO, MJA., SIQUEIRAFILHO, JA. and SILVA, SI. 2010. Checklist das macrófitas vasculares de Pernambuco: riqueza de espécies, formas biológicas e consideraçóes sobre distribuição. In ALBUQUERQUE, UP., MOURA, AN. and ARAÚJO, EL. (Eds.). Biodiversidade, potencial econômico e processos ecofisiológicos em ecossistemas nordestinos. vol. II. p. 253-280.

TAKEDA, AM., SOUZA-FRANCO, GM., MELO, SM. and MONKOLSKI, A. 2003. Invertebrados associados às macrófitas aquáticas da planície de inundação do alto rio Paraná (Brasil). In THOMAZ, S. and BINI, LM. (Eds.). Ecologia e Manejo de Macrófitas Aquáticas. Maringá: Eduem. p. 243-260.

TAVARES, KS. 2003. A comunidade de macrófitas aquáticas em reservatórios do Médio e Baixo Tietê (SP) e em lagoas da Bacia do Médio Rio Doce (MG). São Carlos: Universidade Federal de São Carlos. [Master thesis].

TAVARES, KS., ROCHA, O., ESPÍNDOLA, ELG. and DORNFELD, CB. 2004. Composição taxonômica de macrófitas aquáticas do reservatório de Salto Grande. (Americana, SP). In ESPÍNDOLA, ELG., LEITE, MA. and DORNFELD, CB. Reservatório de Salto Grande (Americana, SP): caracterização, Impactos e Propostas de Manejo. São Carlos: Rima Editora. p. 239-252.

THOMAZ, SM., BINI, LM. and PAGIORO, TA. Macrófitas aquáticas em Itaipu: ecologia e perspectivas para o manejo. In THOMAZ, SM. \& BINI, LM. (Eds.). Ecologia e manejo de macrófitas aquáticas. Maringá: Eduem, 2003. p. 319-341.

VAN DEN BERG, MS., H. COOPS, R. NOORDHUIS, J. VAN SCHIE and J. SIMONS. 1997. Macroinvertebrate communities in relation to submerged vegetation in two Chara-dominated lakes. Hydrobiologia, vol. 342/343, p. 143-150.

VELÁSQUEZ, J. 1994. Plantas acuáticas vasculares de Venezuela. Caracas: Universidad Central de Venezuela. Consejo de Desarrollo Científico y Humanístico. 992 p.

VIANA, SM. 2005. Riqueza e distribuição de macrófitas aquáticas no rio monjolinho e tributários (São Carlos, SP) e análise de sua relação com as variáveis físicas e químicas. São Carlos: Escola de Engenharia de São Carlos. [Master thesis].

Received: 03 March 2010 Accepted: 12 August 2010 